\title{
A koleszterincsökkentés nem a Szent Grál, de nem is az ördög múve
}

\author{
Bajnok László
}

Pécsi Tudományegyetem, I. sz. Belgyógyászati Klinika, Endokrinológiai és Anyagcsere Tanszék, Pécs

Levelezési cím:

Prof. dr. Bajnok László, 7624 Pécs, Ifjúság út 13., e-mail: bajnok.laszlo@pte.hu

\begin{abstract}
A koleszterincsökkentő statinok a legjobban bevizsgált készítmények a hatás és mellékhatás tekintetében. Ezek alapján tudjuk biztonsággal állítani, hogy a koleszterincsökkentő ellenes vélemények zöme nem valóság alapú. Nem csodaszerekről van szó, de rendszeres szedésükkel - bizonyítottan - 30\% körüli mértékủ kardio- és cerebrovaszkuláris kockázatcsökkenés érhetö el, miközben a mellékhatások és kockázatok gyakorisága minden betegcsoportnál legalább egy nagyságrenddel kisebb. Nincs koleszterin „labor normálérték”, nincs túl alacsony, csak "célérték”, mert az átlagérték az ateroszklerózis szempontjából magas (a születéskori és a természeti népeknél megmaradó érték tekinthető normálisnak).

Becsüljük meg a koleszterincsökkentőket, mert nem olyan nagy a fegyvertárunk!
\end{abstract}

Kulcsszavak: koleszterin, statinok, kardiovaszkuláris kockázat, cerebrovaszkuláris kockázat

\section{Cholesterol-lowering is not the Holy Grail, but neither is the work of the devil}

Cholesterol-lowering statins are the most tested medications in respect of the effects and side-effects. Based on these, we can safely claim that most of the negative opinions about cholesterol-lowering are not realistic. It is not a panacea, but it is proven that around a $30 \%$ of cardio- and cerebrovascular risk reduction can be achieved by their regular taking, while the incidence of side effects and risks are at least one order of magnitude lower in each patient groups. For cholesterol, there is no "normal" lab threshold or low level, only "target values", since the mean value in the general population is high in regard of atherosclerosis (the values measured at birth and among natural people can be considered normal). Let us appreciate the cholesterol-lowering medications because we do not have a large armamentarium!

Keywords: cholesterol, statins, cardiovascular risk, cerebrovascular risk

\section{Bevezetés}

A koleszterincsökkentést ellenző vélemények az utóbbi időben felerősödtek. Jelen közlemény érveket kíván felhozni ezek ellen, olyan stílusban, ami a reményeink szerint laikus érdeklődők számára is érthető.

\section{A koleszterincsökkentés és ellenesség to̊rténete}

A koleszterincsökkentéssel kapcsolatos ádáz vita több évtizedes, annak ellenére, hogy a szentpétervári Nyikoláj Anyicskov azért tudott koleszterinetetéses nyúl 
ateroszklerózis modellt létrehozni, mert felfedezte, hogy az emberi ateroszklerotikus artériák bizonyos (azóta Anyicskovnak nevezett) sejtjeiben halmozódik fel az a sárgás anyag, amit koleszterinnek nevezünk (1). Az emberek legalább fele ma nálunk az ebböl eredő szív és érrendszeri (kardiovaszkuláris) betegségben fog szenvedni és/vagy meghalni (2). Joseph Goldstein és Michael Brown 1985-ben Nobel-díjat a vér koleszterinszint szabályozási mechanizmusának feltárásában és egy korszerü koleszterincsökkentő gyógyszercsalád, a statinok ez alapján történő kifejlesztésében játszott kiemelkedő szerepéért kapott (3). Az elkövetkező évek nagy, statinokkal végzett vizsgálatainak robosztus pozitív eredményei fényesen igazolták, hogy valóban milyen kiemelkedő (Nobel-díjat messze meghaladó) jelentőségủ felfedezésről volt szó és ráadásul a statinok biztonságos készítményeknek bizonyultak (4-6). Különösen kellemes meglepetés volt, hogy a statinok nemcsak a koszorúér-betegség, hanem a szélhűdés kockázatát is képesek csökkenteni (5), annak ellenére, hogy a koleszterinszint és agyi érbetegségek okozta halálozás között nem mutatható ki olyan összefüggés, mint a koszorúér-betegség vonatkozásában (7). Az új évezred küszöbén úgy tünt, hogy a tudományosság kellő meggyőző erőt képvisel. Ennek pozitív példáját szolgáltatta az a munkacsoport, amelyik először az erőszakos halálozás koleszterincsökkentéssel kapcsolatos növekedését mutatta ki, majd tíz évvel később - sok százezer betegév tanulságai alapján - ezen aggályokat megnyugtatóan elvetette $(8,9)$. A „mainstream” tudomány győzelme azonban csak látszólagos volt, a „koleszterin szkeptikus", különböző szintű véleményalkotók és az ezek által tematizált közvélemény újra és újra az egész koncepciót tagadták, tagadják és támadták, támadják (10). A küzdelem a legmagasabb brit tudományos fórumokat is involválja, tudománypolitikai presztízskérdéssé avanzsálva (11), de legnagyobb társadalmi hatása a médiának van, s könnyen ennek kereszttüzében találhatják magukat a tudományos világban elismert, megdöbbent szakemberek is, dehonesztáltan, a hamis próféták vagy korrupt haszonlesők pozíciójában, kipellengérezetten (12). A tudományos és a hangoskodó közvélemény ellentétes mozgásának paradoxonjára misem jellemzőbb, hogy a koleszterinröl azóta is rendre az derül ki a nagy vizsgálatokban, hogy nincs olyan alacsony érték, aminél alacsonyabb ne lenne jobb (13). És ezt a tudomány alapvetően nem is vitatja (a hatékonyság összetevőit és költség-hatékonyságát már igen). Nehéz megmondani, hogy miért nem például a vérnyomáscsökkentés körül alakult ki ilyen antagonizmus, ahol az alacsonyabb vérnyomás célértékek célszerüségéröl (mi a vállalható, hatékony és biztonságos alsó érték?) intenzív viták zajlanak a tudományos világban is (14). Szerepet játszhat ebben az is, hogy a magas vérnyomás területén a nagy gyógyszervizsgálatok évtizedekkel előbb lettek sikeresek (a hipertónia előtti esszenciális jelző még annak a kornak az öröksége, amikor az a nézet uralkodott, hogy
1. TÁBLÁZAT. A koleszterincsökkentő kezelés javallatát meghatározó LDL-C értékek és kardiovaszkuláris (KV) kockázati kategóriák, az Európai Kardiológus Társaság szerint

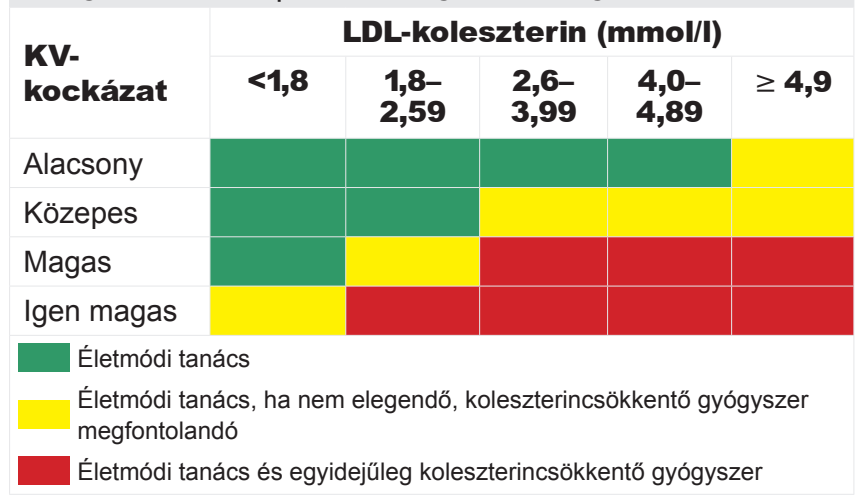

ez jó, a szervek megfelelő keringéséhez esszenciálisan szükséges vérnyomás).

\section{Mit mondanak a tudományos társaságok ajánlásai?}

Valamennyi ajánlás a világban a statinok általános alkalmazását vagy annak megfontolását javasolja, már a köztes - egészséges középkorúakra jellemző - mértékü szív-érrendszeri kockázattól kezdve $(2,15-18)$. Tehát a koleszterin és a kockázat együttesen határozzák meg a tennivalókat (ezért értelmetlen labor „normálértékről” beszélni). Az Európai Kardiológiai Társaság ilyen ajánlását, az egyik aterogén koleszterin, az LDL-koleszterin értékének a függvényében az 1. táblázatban tüntettük fel (2, 15). Ennek szellemében nézzük egy 40 éves (panasz-, tünetmentes, negatív háziorvosi vizsgálatú és laború) magyar férfi vagy 50 éves nő példáját, akinek a kardiovaszkuláris kockázata már olyan mértékű (közepes, mivel az ezt jellemző érték, az ún. SCORE: 1, függetlenül az esetleges dohányzástól), hogy az európai ajánlás alapján a koleszterincsökkentő gyógyszeres kezelés már megfontolandó. (Erről a megcélzott, de sokszor kétkedő páciensnek magam fóliázott, rövid betegtájékoztatót adok, ami egyébként a PTE KK I. sz. Belgyógyászati Klinika honlapján, a dokumentumtárban, a munkacsoporthoz nem rendelt anyagok között is fellelhetö) (19). A magyar prevenciós konszenzus ajánlás a közepes kockázat alsó határát illetően kissé tartózkodóbb (SCORE: 2), amit ugyanezen egyének tíz évvel később érnek el; az amerikai irányelvek (17) szerint azonban nekik már ilyenkor határozottan ajánlott a statin (tehát egy 50 éves „egészséges” magyar férfinak vagy egy 60 éves nőnek megfelelö kockázat mérséklésére, akkor is, ha az illető nem dohányzik és nem magas a vérnyomása). Másrészt viszont ezen egyéneknek nincs - a védőoltásokon kívül - egyéb bizonyított és ajánlott gyógyszeres prevenció (sem vénynélküli készítmény, táplálék-kiegészítö) $(2,15)$. Az Európai Kardiológiai Társaság például határozottan ellenzi a vérlemezkegátló aszpirin (például gyógyszer- 
cég promóciója alapján történő) alkalmazását, kivéve, ha már van igazolt kardiovaszkuláris betegség. Különös óvatosság igényeltetik a bevizsgálatlan készítményekkel kapcsolatban, mert a tetszetős hipotézisek - például a vitaminokkal kapcsolatban - ártalomhoz vezethetnek (akár rákkeltőek is lehetnek) (20).

\section{Kinek van igaza?}

A tudomány tehát bizton állíthatja, hogy a koleszterincsökkentők a legbiztonságosabb gyógyszerek közé tartoznak, és mindig lényegesen nagyobb a tölük várható haszon, mint a kockázat. Nézzük, milyen ellenbizonyítékok vannak arra nézve, hogy mindez teljesen alaptalan, légből kapott koholmány, mint azt a nagy koleszterin összeesküvés hívői állítják?

Miért hisszük el, hogy a szívkoszorúér-tágítás vagy mútét, vagy a vér alvadékonyságát befolyásoló szerek több hasznot hajtanak (akinél hajtanak), mint amennyi veszélyt hordoznak? Mert hiszünk a tudománynak, az eredményeinek és a bizonyítékainak. Elhisszük - akik meg csináljuk, közelről látjuk - hogy ezeket a vizsgálatokat, lényegüket illetően nem lehet manipulálni. Mint ahogy azt is elhisszük, hogy a szív-ér rendszeri betegségek lefolyása a világban is és Magyarországon is valóban (és nemcsak hamis statisztikákban) javul, a várható élettartam nő (a társadalom öregszik) és ebben az orvostudománynak is van (lehet) szerepe.

Miért csak a statinokkal esküdött össze a nemzetközi karvalytőke és a megvett kuruzsló vazallushad? A többi (mód)szerben nincs annyi üzlet? Ezeknek a vizsgálatait miért fogadjuk el (ha elfogadjuk). A generikus statinok tényleg akkora pénzforgalmat tudnak generálni, amivel valamennyi nagy nemzetközi kardiológiai és egyéb szervezet - élén a szakmaiságát és financiális függetlenségét féltve őrző USPSTF-fel (18) - megvehető? Amennyiben igen, úgy az amerikai szenátusi meghallgatások szintjére kellene tudni vinni egy ilyen horderejü, korrupciógyanús ügyet, mint ahogyan Steven Nissen tette a rosiglitazonnal (21).

(Ha lehetne, a Pfizer miért rázkódott volna bele egy lipid szerének - a torcetrapibnak - a bukásába?) (22).

\section{Az időseknek árt vagy használ a koleszterincsökkentés?}

A koleszterin-szkeptikusok egyik elemzésében az idősek halálozása alacsonyabb volt magas koleszterinértékek mellett (10). Azonban a reprezentatív, teljes körü, nem kimazsolázott elemzések mást mutatnak. Az ilyen, többszázezer egyén adatait feldolgozó epidemiológiai vizsgálatok teljesen egyértelmúek az aterogén lipidek, így a koleszterin és az ateroszklerotikus események közötti kapcsolat exponenciális jellegét illetően, valamennyi életkori csoportban $(7,23)$. Azért lényeges e területen a megfelelő minőségű, hiteles, nem előítéletes feldolgozás, mert a társbetegségek „fordított oksági" torzulást okozhatnak (24). Még fontosabb azonban, hogy a koleszterincsökkentőkkel végzett véletlen besorolásos, ellenőrzött kardiovaszkuláris végpontos vizsgálatok összesítetten 169138 betegének sorsát elemezve valamennyi vizsgált - kor, nem, testsúly, dohányzás és a legkülönbözőbb társbetegségek szerint képzett - betegcsoportban univerzális és a koleszterincsökkenés mértékével arányos hatékonyság igazolódott - így a fiatalabbakhoz képest a 75 év felettiek esetében sem volt statisztikai különbség az adatokban (4). Ugyanakkor az abszolút haszon az életkor elörehaladtával nő (25). Ezek alapján - bizonyos halvány fikciók sugallatára - megfosztani egyes csoportokat, például az időseket a korszerű kezeléstől azért lenne etikátlan, mert nem felelne meg a korszerü, bizonyítékokon alapuló orvoslásnak.

\section{Az életmódkezelés valódi alternatívăja a gyógyszeres koleszterincsőkkentésnek?}

Vonzó elképzelésnek tűnhet, hogy az egészséges életmód a gyógyszeres kezelés, így a koleszterincsökkentés alternatívája lehet. Már az egészséges életmód meghatározásával is gondok adódnak. Ugyanis a szélsőségesen szénhidrátszegény étrendet egyetlen mértékadó táplálkozástudományi irányelv sem támogatja (26) és a teljes kiőrlésű gabonafélék az egészséges táplálkozás oszlopos részét képezik, azért is, mert ennek kardiovaszkuláris és teljes halálozást csökkentő hatását nagy prospektív kohorsz vizsgálatok igazolták (27). Még nagyobb baj, hogy nincsen a gyakorlatban is alkalmazható életmódkezeléssel végzett véletlen besorolásos, ellenőrzött, meggyőzően sikeres kardiovaszkuláris eredményű vizsgálat (sikertelen igen) (28), tehát nem tekinthető bizonyítottnak, hogy a gyógyszeres kezelés alternatívája lehetne. Egyébként a koleszterin az életmóddal egyik legnehezebben befolyásolható kockázati tényező (szemben a másik vérzsír összetevővel, a trigliceriddel vagy a vércukorral) (2).

\section{Mennyire ártalmas valójában a koleszterincsökkentés?}

A statinokkal kapcsolatos, közhiedelemben elterjedt téves nézetek közül talán a legirreálisabb a májkárosodástól való félelem. Ugyanis bár a májenzim-emelkedés nem kivételes - a dózistól és szertől függően 0,2-2,1\% közötti gyakoriságú - de a súlyos forma nagyon ritka (<1/10 000 beteg) és esetlegesen idültté váló esetek megszaporodását megbízható adatbázisokban nem lehetett kimutatni (29). Pedig a tudomány sosem tagadta le a statinokról kiderülő valódi mellékhatásokat. Így megállapításra és széles körben publikálásra került, 


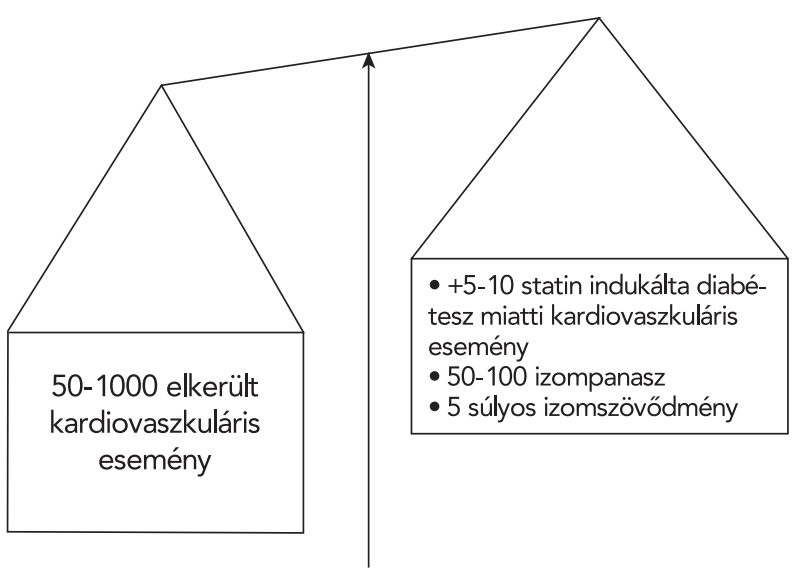

1. ÁBRA. A statinkezelés potenciális kardiovaszkuláris haszna és kockázata 10000 beteg, 5 éves kezelésekor

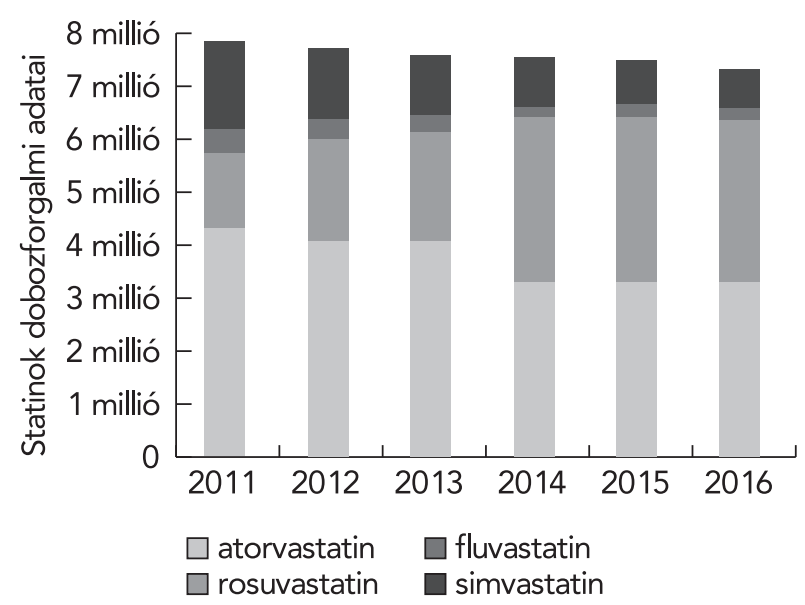

2. ÁBRA. Kiváltott statin dobozforgalmi adatok (OEP/NEAK adatok alapján)

hogy a statinok a cukorbetegség (diabétesz) kockázatát mérsékelten (dózisfüggő módon 9-26\%-kal), de emelik. Ez azt jelenti, hogy minden 4-10. kialakuló diabétesz statinnal kapcsolatos, az ezt szedő egyén esetében (de egyben azt is, hogy az esetek döntő hányadában viszont ettől függetlenül alakul ki a betegség).

A véletlen besorolásos, ellenőrzött vizsgálatok alapján az objektíven statinszedés okozta izompanaszok gyakorisága 1\% alatti, a súlyos izomszövődményeké pedig legalább egy nagyságrenddel ritkább $(29,30)$, és ez nem magyarázható pusztán a klinikai vizsgálatok betegszelekciós elveivel és gyakorlatával. A szubjektív izomtünetek nagy része nem magával a statinnal kapcsolatos és általában - átmeneti szünetek utáni újrakezdésekkel - megszünik $(29,30)$. Viszont tudjuk, hogy a betegtájékoztató fokozza a lehetséges, részletezett panaszok jelentkezését (ez az ún. nocebo hatás) (31). A haszon és kockázat arányát az 1. ábra érzékelteti (29).

\section{Következtetések}

A koleszterincsökkentőkkel szembeni demagógia sikerességét jelzi, hogy a hazai statin dobozforgalmi adatok - mint azt a 2. ábra adatai tükrözik - az elmúlt években csökkentek és nem az orvostudomány szerint kívánatos módon nőttek (32). Az életmód és gyógyszeres kezelés sokkal inkább komplementerei, mint alternatívái egymásnak. Miért ne használnánk ki mindkét lehetőséget? Még így is marad bőven (reziduális) kockázat. Sokan és sokat mondják, hogy „fő az egészség”, de sokszor az egészség (is) jobbára csak az ördög üstjében fö.

\section{Irodalom}

1. Classics in arteriosclerosis research: On experimental cholesterin steatosis and its significance in the origin of some pathological processes by Anitschkow N, Chalatow S, translated by Mary Z. Pelias, 1913. Arteriosclerosis 1983 Mar-Apr; 3(2): 178-82. https://dx.doi. org/doi:10.1161/01.ATV.3.2.178

2. Catapano AL, Graham I, De Backer G, et al. 2016 ESC/EAS Guidelines for the Management of Dyslipidaemias: The Task Force for the Management of Dyslipidaemias of the European Society of Cardiology (ESC) and European Atherosclerosis Society (EAS) Developed with the special contribution of the European Association for Cardiovascular Prevention \& Rehabilitation (EACPR). Eur Heart $J$ 2016 Aug 27. pii: ehw272. https://dx.doi.org/doi:10.1093/eurheartj/ ehw272

3. Motulsky AG. The 1985 Nobel Prize in physiology or medicine. Science 1986; 231: 126-9. https://dx.doi.org/doi:10.1126/science. 3510453

4. Cholesterol Treatment Trialists' (CTT) Collaboration. Efficacy and safety of more intensive lowering of LDL cholesterol: a meta-analysis of data from 170,000 participants in 26 randomised trials. Lancet 2010; 376: 1670-1681. https://dx.doi.org/doi:10.1016/S01406736(10)61350-5

5. Cholesterol Treatment Trialists' (CTT) Collaboration. Efficacy and safety of LDL-lowering therapy among men and women: meta-analysis of individual data from 174000 participants in 27 randomised trials. Lancet 2015; 385: 1397-405. https://dx.doi.org/doi:10.1016/ S0140-6736(14)61368-4

6. Chou R, Dana T, Blazina I, et al. Statin Use for the Prevention of Cardiovascular Disease in Adults: A Systematic Review for the U.S. Preventive Services Task Force [Internet]. Rockville (MD): Agency for Healthcare Research and Quality (US); 2016 Nov. Report No.: 14-05206-EF-2. U.S. Preventive Services Task Force Evidence Syntheses, formerly Systematic Evidence Reviews. https://dx.doi.org/ doi:10.1001/jama.2016.15450

7. Prospective Studies Collaboration, Lewington S, Whitlock G, Clarke $\mathrm{R}$, et al. Blood cholesterol and vascular mortality by age, sex, and blood pressure: a meta-analysis of individual data from 61 prospective studies with 55,000 vascular deaths. Lancet 2007; 370: 1829 1839. https://dx.doi.org/doi:10.1016/S0140-6736(07)61778-4

8. Muldoon MF, Manuck SB, Matthews KA. Lowering cholesterol concentrations and mortality: a quantitative review of primary prevention trials. BMJ 1990; 301: 309-14. https://dx.doi.org/doi:10.1136/ bmj.301.6747.309

9. Muldoon MF, Manuck SB, Mendelsohn AB, et al. Cholesterol reduction and non-illness mortality: meta-analysis of randomised clinical trials. BMJ 2001; 322: 11-5. https://dx.doi.org/doi:10.1136/ bmj.322.7277.11

10. Ravnskov U, Diamond DM, Hama R, et al. Lack of an association 
or an inverse association between low-density-lipoprotein cholesterol and mortality in the elderly: a systematic review. BMJ Open 2016; 6: e010401. https://dx.doi.org/doi:10.1136/bmjopen-2015-010401

11. Horton R. Offline: Lessons from the controversy over statins. Lancet 2016; DOI:10.1016/S0140-6736(16)31583-5. Editorial. https://dx.doi.org/doi:

12. Schiele F, Kristensen SD. The anti-statin lobby strikes again: time to set the record straight. Eur Heart J 2017 Dec 28. doi: 10.1093/eurheartj/ehx744. https://dx.doi.org/doi:10.1016/S01406736(16)31357-5

13. Giugliano RP, Pedersen TR, Park JG, et al. Clinical efficacy and safety of achieving very low LDL-cholesterol concentrations with the PCSK9 inhibitor evolocumab: a prespecified secondary analysis of the FOURIER trial. Lancet 2017; 390: 1962-1971. https://dx.doi.org/ doi:10.1016/S0140-6736(17)32290-0

14. Kiss I, Kékes E. A SPRINT vizsgálat eredményeinek kritikája és gyakorlati értéke. Hypertonia és Nephrologia 2017; 21: 34-36.

15. Piepoli MF, Hoes AW, Agewall S, et al. 2016 European Guidelines on cardiovascular disease prevention in clinical practice: The Sixth Joint Task Force of the European Society of Cardiology and Other Societies on Cardiovascular Disease Prevention in Clinical Practice. Eur Heart J 2016; 37: 2315-81. https://dx.doi.org/ doi:10.1093/eurheartj/ehw106

16. Jacobson TA, Ito MK, Maki KC, et al. National Lipid Association recommendations for patient-centered management of dyslipidemia: part 1 - executive summary. J Clin Lipidol 2014; 8: 473-88. https://dx.doi.org/doi:10.1016/j.jacl.2014.07.007

17. Stone NJ, Robinson J, Lichtenstein AH, et al. 2013 ACC/AHA Guideline on the Treatment of Blood Cholesterol to Reduce Atherosclerotic Cardiovascular Risk in Adults: A Report of the American College of Cardiology/American Heart Association Task Force on Practice Guidelines. J Am Coll Cardiol 2013; pii: S0735-1097(13)06028-2. https://dx.doi.org/doi:10.1016/j.jacc.2013.11.002

18. US Preventive Services Task Force. Statin Use for the Primary Prevention of Cardiovascular Disease in Adults: US Preventive Services Task Force Recommendation Statement. JAMA 2016; 316: 1997-2007. https://dx.doi.org/doi:10.1001/jama.2016.15450

19. http://aok.pte.hu/hu/egyseg/dokumentumok/260

20. Brasky TM, White E, Chen CL. Long-Term, Supplemental, One-Carbon Metabolism-Related Vitamin B Use in Relation to Lung Cancer Risk in the Vitamins and Lifestyle (VITAL) Cohort. J Clin Oncol 2017; 35: 3440-3448. https://dx.doi.org/doi:10.1200/ JCO.2017.72.7735
21. Staff Report of the GlaxoSmithKline and the Diabetes Drug Avandia. Prepared by the staff of the Committee on Finance, United States Senate, Max Baucus, Chairman, Chuck Grassley, Ranking member. http://finance.sen.gov/press/Gpress/2010/prg022010a.pdf 22. Barter PJ, Caulfield M, Eriksson M, Grundy SM, et al. Effects of torcetrapib in patients at high risk for coronary events. $\mathrm{N}$ Engl J Med 2007; 357: 2109-22. https://dx.doi.org/doi:10.1056/NEJMoa0706628

23. Emerging Risk Factors C, Di Angelantonio E, Gao P, Pennells $\mathrm{L}$, et al. Lipid-related markers and cardiovascular disease prediction. JAMA 2012; 307: 2499-2506. https://dx.doi.org/doi:10.1001/ jama.2012.6571

24. Law MR, Thompson SG, Wald NJ. Assessing possible hazards of reducing serum cholesterol. BMJ 1994; 308: 373-79. https://dx. doi.org/doi:10.1136/bmj.308.6925.373

25. Braunwald E. Reduction of LDL-cholesterol: important at all ages. Eur Heart J 2016; 37: 1982-1984. https://dx.doi.org/doi:10.1093/eurheartj/ehw100

26. Scientific Report of the 2015 Dietary Guidelines Advisory Committee. http://www.health.gov/dietaryguidelines/2015-scientific-report/ 27. Wu H, Flint AJ, Qi Q, et al. Association between dietary whole-grain intake and risk of mortality two large prospective studies in US men and women. JAMA Intern Med 2015; 175: 373-84. https:// dx.doi.org/doi:10.1001/jamainternmed.2014.6283

28. Look AHEAD Research Group, Wing RR, Bolin P, Brancati FL, et al. Cardiovascular effects of intensive lifestyle intervention in type 2 diabetes. N Engl J Med 2013; 369: 145-54. https://dx.doi.org/ doi:10.1056/NEJMoa1212914

29. Collins R, Reith $C$, Emberson J, et al. Interpretation of the evidence for the efficacy and safety of statin therapy. Lancet 2016; 388: 2532-2561. https://dx.doi.org/doi:10.1016/S0140-6736(16)31357-5

30. Stroes ES, Thompson PD, Corsini A, et al. Statin-associated muscle symptoms: impact on statin therapy-European Atherosclerosis Society Consensus Panel Statement on Assessment, Aetiology and Management. Eur Heart J 2015; 36: 1012-22. https://dx.doi.org/ doi:10.1093/eurheartj/ehv043

31. Finegold JA, Manisty $\mathrm{CH}$, Goldacre B, et al. What proportion of symptomatic side effects in patients taking statins are genuinely caused by the drug? Systematic review of randomized placebo-controlled trials to aid individual patient choice. Eur J Prev Cardiol 2014; 21 : 464-74. https://dx.doi.org/doi:10.1177/2047487314525531

32. http://www.neak.gov.hu/felso_menu/szakmai_oldalak/publikus forgalmi_adatok/gyogyszer_forgalmi_adatok 